\title{
Persian Renderings of English Conceptual Discourse Patterns: A Case Study of Animal Farm
}

\author{
Esmail Faghih \\ Islamic Azad University South Tehran Branch, Iran \\ Roya Moghiti (Corresponding author) \\ Islamic Azad University South Tehran Branch, Iran
}

Received: 13-05-2017

doi:10.7575/aiac.ijclts.v.5n.3p.55
Accepted: 27-06-2017

Published: 31-07-2017

URL: http://dx.doi.org/10.7575/aiac.ijclts.v.5n.3p.55

\begin{abstract}
Discourse includes both structural and conceptual patterns. Most of these patterns are different in various languages. A conceptual pattern in source language can be realized in different ways in target language. Therefore, the translator should be aware of differences between SL and TL conceptual patterns because rendering these patterns from the source text into the target one can be problematic. The present descriptive study aimed to investigate the conceptual discourse patterns and related ideologies in George Orwell's Animal Farm and its Persian translations. Accordingly, the researchers selected and analyzed the samples based on Fairclough's (2001) approach to CDA. Based on the findings, Gheybi (2010) has been more successful in rendering the conceptual discourse patterns and ideologies, because her translation was much more similar to the source text in terms of conceptual discourse patterns as compared to the translation by Hoseyni and Nabizadeh (2003). The findings indicated that the translators' ideological and socio-cultural norms affect their translation strategies and lexical and grammatical choices and this in turn influences their success to recognize and transmit the ST implicit ideologies into TT.
\end{abstract}

Keywords: Conceptual Discourse Patterns, Renderings

\section{Introduction}

Jan-Ola Ostman (as cited in Bublitz \& Lenk 1997, p.97) defines discourse pattern as "part of what we conceive of as the coherence of text/discourse is a chord in the kind of global, cognitive, partly codified understanding we have of how to categorize the text/discourse in question and how to hook this text/discourse onto the cognitive frame of understanding that I call a discursive pattern". He also has mentioned that "discursive patterns are cognitive schemata in accordance with which a text or discourse is characterized, in terms of which it receives coherence, and in terms of which texts and discourse are readily interpretable and understandable as being of that particular kind". (As cited in Bublitz \& Lenk 1997, p.84)

In order to understand how a translator as TT reproducer should clarify the implicit ideologies and social power underlying discourses, theorists (e.g. Aidinlou, Dehghan, \& Khorsand, 2014; Li, 2013) have attempted to define the relationship between CDA and TS. They defined CDA as a critical approach to explicate power relationships that are in many cases hidden to represent the inequality and to discover the links between textual structures and their functions in interaction within the society (see Wales, 2014; Lafta, 2015). Discourse with structural and conceptual properties is originated from the backgrounds and social contexts. Therefore, CDA as a useful instrument can be used to analyze the structural and conceptual discourse patterns in both ST and TT as two different discourses. In other words, discourse has both structural and conceptual patterns, and readers and hearers use both, in a framework of contextual information, and in interpreting the text. Discourse patterns are generally not rule-bound as in lower-level grammar, but are more flexible, reflecting underlying conceptual patterns more directly. In fact, many structural discourse patterns can be thought of as epiphenomena of conceptual patterns. However, it does not follow that all languages have the same structural discourse patterns: a given conceptual pattern can be realized in different ways in different languages. It is for this reason that copying patterns from the source text can be a problem. (Dooley, 2008, p.3)

The discourse patterns (the logical arrangement of ideas) of an expository text or of an oral presentation for informational purposes will vary depending on culture and the native language of the writer/speaker. That is, logic is not universal, i.e., the logical arrangement of ideas is culture-bound. Therefore, the present researchers tried to analyze the conceptual discourse patterns both in source and target texts based on Fairclough's (2001) CDA method in order to figure out whether the conceptual discourse patterns have been translated from English into Farsi and to what extent there have been losses of meaning.

To achieve the objectives of this study, the following two research questions were posed:

RQ1. Have the Farsi translators succeeded in transferring Orwell's conceptual discourse patterns from English into Farsi?

RQ2. Have the Farsi translators succeeded in transferring the ideologies of the English source text into Farsi text? 


\section{Methodology}

Considering the purpose of the study, the materials should support the ideological and power concepts; therefore, the present researchers have used Animal Farm by George Orwell and two of its Farsi translations in order to answer the research questions and achieve the objectives of this study.

Animal Farm is an allegorical and dystopian novel by George Orwell, first published by Martin Secker and Warburg in England on 17 August 1945. According to Orwell (1946), the book reflects events leading up to the Russian Revolution of 1917 and then on the Stalinist era of the Soviet Union. Orwell has been claiming that every word of his professional work was written to express his discontent and disgust for totalitarian rule. Orwell described Animal Farm as a satirical tale against Stalin and in his essay "Why I Write" (Orwell,1946), wrote that Animal Farm was the first book in which he tried, with full consciousness of what he was doing, "to fuse political purpose and artistic purpose into one whole".

مزرعه حيوان/mazra'iyi hiyvānāt/ chosen by the researchers, is Farsi translation A of Animal Farm by George Orwell. This novel, translated into Farsi by Marjan Gheybi was published by Entesharate Rahnama in Tehran, 2011.

مزر عه حيوانات/mazra'iyi hiyvānāt/ chosen by the researchers, is Farsi translation B of Animal Farm by George Orwell. This novel, translated into Farsi by Saleh Hoseyni and Maasoomeh Nabizadeh was published by Entesharate Doostan in Tehran, 2003.

To carry out this study, the following steps were taken:

1. The original source material was read line by line by the researchers and the conceptual discourse patterns were realized regarding lexical and grammatical features. The same was done on its Farsi translations. Look at the following example extracted from Animal Farm by Orwell (1945):

English Example: No animal shall wear clothes. (Orwell, 1945, p.16)

Farsi Translation 1: (Gheybi, 2011, p.39)

$$
\text { هيج حيو انى نبايد لباس يبوشد. }
$$

/hīch hiyvānī nabāyad libās bipūshad/

Farsi Translation 2: (Hoseyni\& Nabizadeh, 2003, p.28)

$$
\text { هيج حيو انى نبايد لباس برتن كند. }
$$

/hīch hiyvānī nabāyad libās bartan kunad/

2. Critical Discourse Analysis (CDA) given by Fairclough $(2001,2013)$ as an approach was applied in the texts analysis to recognize conceptual discourse patterns in ST and TTs and consequently to uncover hidden ideology.

2.1 In terms of text analysis, the linguistic features (lexicology and grammar) of the text have been described to see how ideological position of the writer and translators are encoded in the texts. Fairclough $(2001,2013)$ states three values for analyzing texts. In this study, the experiential and relational values were investigated. Experiential value deals with contents, knowledge, and beliefs and relational value reveals relations and social relationships that are enacted via the text. In the level of vocabulary, the two criteria, overwording and euphemistic expression, were used to analyze the texts. Then, as suggested by Fairclough (2001), grammar features were analyzed including nominalization, active or passive, and modality connectors.

2.2 The next step was interpreting processes of text production. There are two domains here: interpretation of situation context and interpretation of intertextual context. In the interpretation of situation, the researchers followed questions given by Fairclough $(2001,2013)$ including what's going on, who's involve, what relationships are at issue, and what 's the role of language. In interpretation of intertextual context, presuppositions were in focus.

3. Explanation concerned with the relationship between those processes and social context - how the discourse change or sustain certain social relationship in social structure - was needed.

As for the example above, the sentences have analyzed according to the following steps:

In this example, modal "shall" indicates an obligatory plan for future. Therefore, it has been expressed that pigs have a good plan for animals' future life, and they have the power to achieve this bright future. They can think and write; therefore, they are powerful characters in animal farm and their discourse is a forcible discourse.

4. The researchers looked at the dominant processes in clauses of the text, i.e., how ideology and power are hidden in transitivity.

5. Upon data collection, the next step was to interpret the differences between the writer's and the translators' conceptual discourse patterns. The existed differences in above example are as:

Gheybi (2011) has mentioned this concept in his Farsi translation and Hoseyni and Nabizadeh (2003), in the same way, have managed to transfer Orwell's discourse patterns.

\section{Results and Discussion}

To carry out this study, Fairclough's (2001) CDA approach was used to investigate the conceptual discourse patterns in English source text and their translations into Farsi. Fairclough $(2001,2013)$ has suggested a set of questions involving strategies that help analyze the discourse critically. Through the questions, he distinguishes three types of values: experiential, relational, and expressive. In this study, the researchers focused on experiential and relational values and the related questions to analyze the samples elicited from the English source text and their translations. In terms of text analysis, the linguistic features (i.e., lexicology and grammar) of the source text were described to see how conceptual 
discourse patterns and ideological positions of the speaker/author were encoded in the text. Vocabulary, as suggested by Fairclough (2001), was analyzed with attention to overwording and euphemistic expressions. Then, grammar features were analyzed including nominalization, passive or active sentences and modality. The researchers tried to investigate whether the translators have succeeded in transferring Orwell's conceptual discourse patterns and ideologies from ST into TTs. According to the context of the source text, the novel of Animal Farm by Orwell (1945), the researchers investigated structural features that refer to patterns in terms of conceptual discourse. Regarding Orwell's patterns and ideological background, the ideological aspects of the related phrases were recognized. In the next step, the researchers compared extracted samples with their two Farsi translations by Gheybi (2011), Hoseyni, and Nabizadeh (2003). In the following sections, the results of study along with an analytic and explanatory discussion are presented in detail.

\subsection{Vocabulary}

In this section, the two following questions along with two English into Farsi examples and a detailed analysis are presented:

1. What experiential values do words have? Is there overwording?

2. What relational values do words have? Are there euphemistic expressions?

\subsubsection{Experiential values and Overwording}

Fairclough (2001, p.93) argues about three values that formal features may have: experiential, relational, and expressive. A feature with experiential value is a trace of and a cue to the way in which the text producers' experiences of the natural or social world are represented. The aspect of experiential value of most interest in the context of Fairclough's work, Language and Power (2001), indicates how ideological differences between texts in their representations of the world are coded in their vocabulary.

According to Fairclough (2001, p.96; 1989, p.115), overwording is identified as "an unusually high degree of wording, often involving many words which are near synonyms". Overwording shows preoccupation with some aspects of reality that may indicate that it is a focus of ideological struggle. Further, Fairclough (1992, p. 193) uses the expression "over-wording" to refer to the relative density of the number of words used to name the concepts from a particular domain, which may be "a sign of intense preoccupation, pointing to peculiarities in the ideology of the group responsible for it". In other words, Fowler (1991, p. 69) describes, over-lexicalization into "the availability of many words for one concept, and indicates the prominence of the concept in a community's beliefs and intellectual interests". To understand what experiential values English and Farsi words have and to see whether there is any overwording in Farsi translations, look at the following example.

English Example: "Loyalty and obedience are more important... Discipline, comrades, iron discipline! (Orwell, 1945, p. 36)

Farsi Translation A: (Gheybi, 2011, p.93)

$$
\text { وفادارى و فرمان بردارى مهم نر است...اطاعت رفقا اطاعت محض. }
$$

/vafādārī va farmānburdārī muhemtar ast... ețā'at rufaqā ețā'ate mahẓ/

Farsi Translation B: (Hoseyni\& Nabizadeh, 2003, p.60)

$$
\text { وفادارى و فرمانبردارى مهم تر است...انضباط, انضباط سفت و سخت. }
$$

/vafādārī va farmānburdārī muhemtar ast... enzẹebāt, enzẹebāte seft va sakht/

Discussion: In this example, the speaker - Squealer- the representative of a totalitarian regime, looking positive to totalitarianism tries to focus on the concept "iron discipline" which indicated no question and no thinking. By using overwordings such as loyalty, obedience, discipline, and iron discipline, the speaker shows her mental patterns in related discourse. Words used by the speaker contain experiential values and express her beliefs. Gheybi (2011) has managed to transfer the speaker's ideology through her translation but using the word "ețā'at", which literary means "obedience" conveys a sense that is a little more forcible instead of fixation of an idea. Hoseyni and Nabizadeh (2003) have also rendered the conceptual discourse pattern and ideology as the speaker. Therefore, it can be concluded that lexical choice has been manipulated the speaker's discoursal pattern in Gheybi's (2010) translation, but Hoseyni and Nabizadeh (2003) have rendered the conceptual pattern and ideology into TTs.

\subsubsection{Relational Values and Euphemistic Expressions}

Regarding the three values, Fairclough (2001, p.93) describes relational value as "a trace of and a cue to the social relationships which are enacted via the text in the discourse". Relational value is to do with relations and social relationships. This question focuses on how a text's choice of wordings depends on, and helps create social relationships between participants. According to Fairclough (2001, p.97), a euphemism is "a word which is substituted for a more conventional or familiar one as a way of avoiding negative values". In a political view, Crespo-Fernández (2014, p.2) argues that euphemism refers to the process whereby the producer makes implicit the inappropriate or offensive word or a distasteful one to provide a "safe" way to deal with certain embarrassing subjects without being politically incorrect or breaking a social convention. It should be mentioned that euphemistic strategies may reflect the politicians' sensitivity to audience's concerns. To understand what relational values English and Farsi words have and to see whether there are any euphemistic expressions in Farsi translations of Animal Farm, look at the following example. 
English Example: He was twelve years old and had lately grown rather stout, but he was still a majesticlooking pig. (Orwell, 1945, p. 1)

Farsi Translation A: (Gheybi, 2011, p.3)

دو ازده ساله بود و اين او اخر كمى هيكل دار شده بود.

/davāzdah sāleh būd va īn avākher kamī heykaldār shudeh būd/

Farsi Translation B: (Hoseyni\& Nabizadeh, 2003, p.15)

دوازده سالى از عمرش مى كنشت و اين او اخر هم خيلى تتومند شده بود.

/davāzdah sālī az umrash mīguzasht va īn avākher ham kheylī tanumand shudeh būd/

Discussion: It is necessary to mention that Orwell shows Old Major, who symbolizes Karl Marx, as so highly regarded character on the farm. To do so, he tries to address him in a polite way and choose more mild and polite-sounding language in order to introduce him. Therefore, he has used the euphemistic word "stout" which shows the respectful relations between animals and Old Major. On the contrary, Gheybi (2011) has translated the expression into "kami heykaldār" which means "a little stout" and Hoseyni and Nabizadeh (2003) have rendered it into "kheyli tanumand" which means "very stout". In both Farsi translations, the ideology of Orwell has been transferred.

\subsection{Grammar}

In this section, the following three questions along with some English into Farsi examples are discussed in detail:

1. What experiential values do grammatical features have? Are nominalizations used?

2. Are sentences active or passive?

3. What relational values do grammatical features have? Are there important features of relational modality?

\subsubsection{Experiential Values of Grammatical Features and Nominalizations}

The experiential aspects of grammar have to do with the ways by which the grammatical forms of a language code happenings or relationships in the world. Fairclough $(2001$, p.100) explains that those "happenings or relationships involve all of the creatures (people, animals or things) and their spatial and temporal circumstances, manner of occurrence, and so on".

Fairclough $(2001,2013)$ explains nominalization as a grammatical process of converting a verb or an adjective into a noun. Through this reduction process, some of the meanings one gets in a sentence are missing like tense; therefore, there is no indication of the timing of the process, modality and often an agent and/or a patient. It indicates that a sentence producer gives priority to actions rather than to the people, responsible for them. Richards and Schmidt (2002, p. 360) identify nominalization as "the grammatical process of forming nouns from other parts of speech, usually verbs or adjectives". Moreover, it can make something that is unclear or uncertain seem stable, powered, and precisely defined.

To understand what experiential values grammatical features have and to see whether there is any nominalization in Farsi translations

English Example: The execution of the traitors this afternoon was the final act. (Orwell, 1945, p.58)

Farsi Translation A: (Gheybi, 2011, p.147)

/e'dāme khā'enīn dar īn ba'd az zuhr ākharīn eqdām būd/$$
\text { اعدام خائنين در اين بعد از ظهر آخرين اقدام بود. }
$$

Farsi Translation B: (Hoseyni\& Nabizadeh, 2003, p.92)

/emrūz ba'd az żuhr kushtane khā’enīn ākharīn eqdām būd/

$$
\text { امروز بعداز ظهر كثنن خائنين آخرين اقدام بود. }
$$

Discussion: The speaker -Squealer- summarizes the act of killing the traitors that shows that the purpose of rebellion has been changed through wording "the execution of the traitors". Here, nominalization helps the speaker depersonalize the agent who has changed the aim, leaves the audience in uncertainty, and makes the action more highlighted. It makes something that is unclear or uncertain seem stable, powered, and precisely defined. Here, the experiential value of the grammatical feature is obvious. Gheybi (2011) has translated the concept as "edāma khā'eni n" which means "the execution of the traitors" from English into Farsi. In addition, Hoseyni and Nabizadeh (2003) have also rendered the discoursal patterns from English into Farsi.

\subsubsection{Passivization}

The process of passivization allows Orwell or speaker to leave out the actor/experiencer/speaker in the sentence. In other words, the real subject of the sentence is missed on purpose. By omitting the performer/doer, the producer can protect sources. In fact, passivization has no such an inherent meaning. That is, meaning is all the time the outcome of a specific reader's inferential processing. To understand whether there is any form of passivization in Farsi translations of Animal Farm, look at the following example.

English Example: the white hoof and horn with which it had previously been marked had now been removed. (Orwell, 1945, p.91)

Farsi Translation A: (Gheybi, 2011, p.231) 
/sume sefīd va shākh keh qablan naqsh basteh būd dar hāle hāzerer bardāshteh shudeh ast/

Farsi Translation B: (Hoseyni\& Nabizadeh, 2003, p.140)

$$
\text { سم و شاخ سفيدى كه قبلا روى آن بود باكى شده است. }
$$

/sum va shākhe sefîdī keh qablan rūye ān būd pāk shudeh ast/

Discussion: As you can see in the story, it is clear that most of the goals of revolution changed after pigs received power. Therefore, to maintain power, as the sign of dictatorship the neighbor, farms should not be aware of this shifting and the speaker (Napoleon) here wants to give less information about the event of changing the flag and deletes the agent. Gheybi (2011) has translated the verb phrase in passive voice as "qablan naqsh basteh būd ... bardāshteh shudeh ast" which literary means "had been marked ...has been removed". In the same way, Hoseyni and Nabizadeh (2003) have managed to transfer Orwell's discoursal patterns into Farsi through the passivization process.

\subsubsection{Relational Values of Grammatical Features and Relational Modality}

There are varieties of grammatical features of the text that have relational values among which modality were the focus of this study. Modality is to do with speaker's or writer's authority. We can look at two aspects of this topic including firstly, a matter of the authority of one participant in relation to others and secondly, a matter of the speaker's or writer's authority with respect to the truth or probability of a representation of reality. Modality is expressed by modal auxiliary verbs. The present study focused on shall, will, must, and can. To understand what relational values grammatical features have and to see whether there is any form of relational modality in Farsi translations of Animal Farm, look at the following example.

English Example: № animal shall kill any other animal. (Orwell, 1945, p.16)

Farsi Translation A: (Gheybi, 2011, p.39)

$$
\text { هيج حيو انى نبايد حيو ان ديكرى را بكثد. }
$$

/hīch heyvānī nabāyad heyvāne dīgarī rā bekushad/

Farsi Translation B: (Hoseyni\& Nabizadeh, 2003, p.28)

$$
\text { هيج حيو انى نبايد حيو ان ديكرى را بكثد. }
$$

/hīch heyvānī nabāyad heyvāne dīgarī rā bekushad/

Discussion: According to the story of Animals Farm by Orwell (1945), Old Major emphasizes animals' duty for enmity towards all Men's ways. This shows his ideologies about the purpose of rebellion. Therefore, for a utopian society, the animals should avoid those ways and seven commandments had been written in forcible tone that illustrated the necessity of rules. Gheybi (2011) as well as Hoseyni and Nabizadeh (2003) have managed to transfer the speaker's discoursal patterns, and forcible tone via modality from English into Farsi and translated "no...shall kill" into "nabāyad ... bekushad".

As previously mentioned, the present study investigated the translation of the discoursal patterns from English into Farsi. Examples of the findings and discussion were presented based on critical discourse analysis. Specifically, the selected lexemes and phrases of the novel "Animals Farm" were compared with their translations into Farsi. The focus was mostly on those features that convey the conceptual or ideological items. Here, the results of the analysis are presented through the tables and figures along with a thorough explanation.

Table 1. Overwording transferred by the Translators

\begin{tabular}{lllll}
\hline Translators & Gheybi (Farsi) & $\begin{array}{l}\text { Hoseyni } \\
\text { (Farsi) }\end{array}$ & and Nabizadeh \\
\hline Criterion & Yes & No & Yes & No \\
\hline Overwording & 9 & 1 & 7 & 3 \\
\hline
\end{tabular}




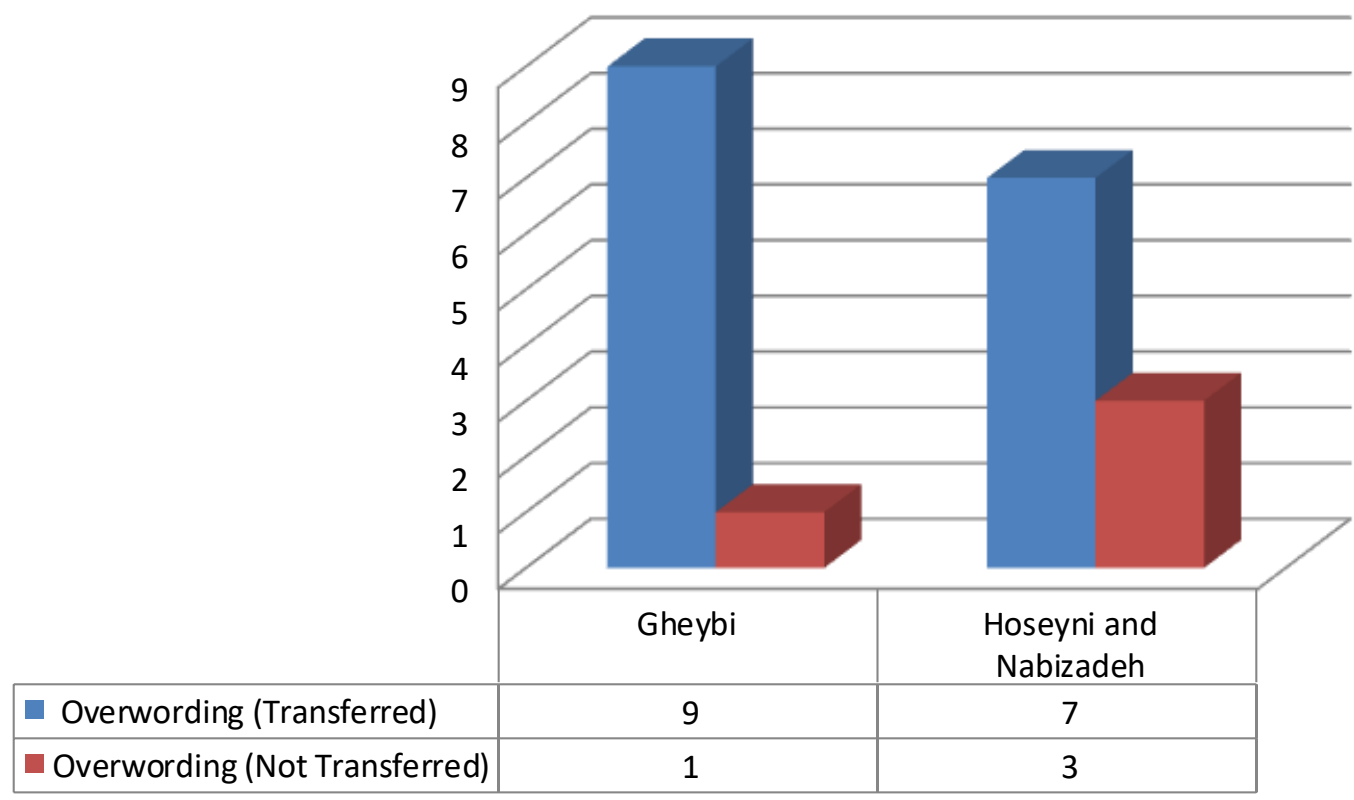

Figure 1. Overwording transferred by the Translators

As shown in Table 1 and Figure 1, Gheybi (2011) has managed to transfer overwording 9 times out of 10 (90\% percent) and has failed to transfer overwording once out of 10 in her Farsi translation. In Farsi translation B, Hoseyni and Nabizadeh have managed to transfer overwording 7 times out of 10 (70\% percent). In Farsi translation B, Hoseyni and Nabizadeh have failed to transfer overwording 3 times out of 10 (37\% percent). This means that the first Farsi translator was more successful in rendering overwording from English into Farsi. That is, Farsi Translation A has better equivalences of the original English ST, than Farsi translation B.

Table 2. Euphemism Transferred by the Translators

\begin{tabular}{lllll}
\hline Translators & Gheybi (Farsi) & $\begin{array}{l}\text { Hoseyni } \\
\text { (Farsi) }\end{array}$ & and Nabizadeh \\
\hline Criterion & Yes & No & Yes & No \\
\hline Euphemism & 5 & 2 & 3 & 4 \\
\hline
\end{tabular}

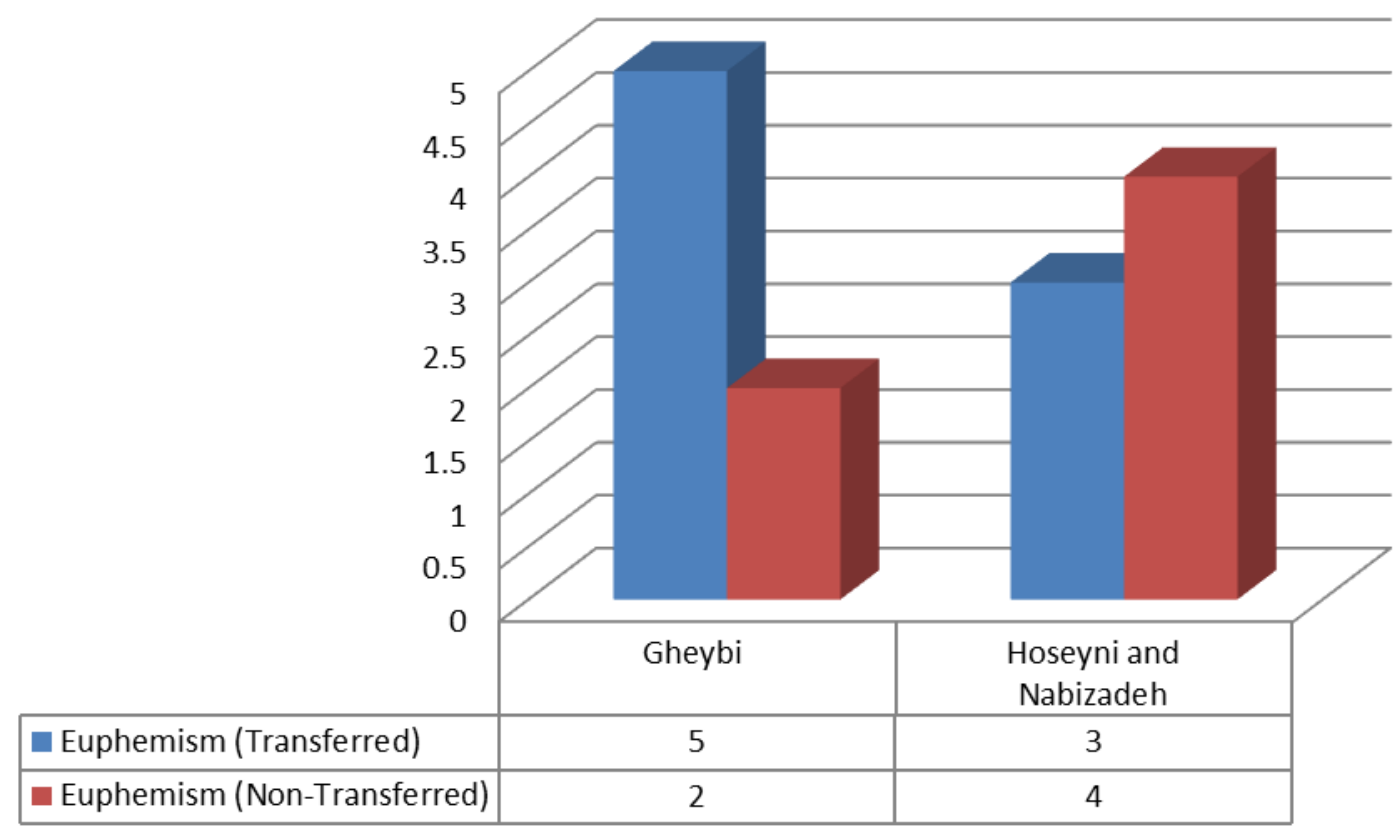

Figure 2. Euphemism Transferred by the Translators 
According to Table 2, as shown in Figure 2, Gheybi (2011) has managed to transfer euphemistic expressions 5 times out of 7 (71\% percent) in her Farsi translation. In Farsi translation B, Hoseyni and Nabizadeh have managed to transfer the euphemistic expressions 3 times out of 7 (43\% percent). On the other hand, Gheybi (2011) has failed to transfer euphemistic expressions 2 times out of 7 (29\% percent) in her Farsi translation. In Farsi translation B, Hoseyni and Nabizadeh have failed to transfer euphemistic expressions 4 times out of 7 (57\% percent). This means that the first Farsi translator was more successful in rendering the euphemism than other translation. That is, Farsi translation A is better equivalence of the original English ST than Farsi translation B.

Table 3. Nominalization Transferred by the Translators

\begin{tabular}{lllll}
\hline Translators & Gheybi (Farsi) & $\begin{array}{l}\text { Hoseyni } \\
\text { (Farsi) }\end{array}$ & and Nabizadeh \\
\hline Criterion & Yes & No & Yes & No \\
\hline Nominalization & 7 & 0 & 6 & 1 \\
\hline
\end{tabular}

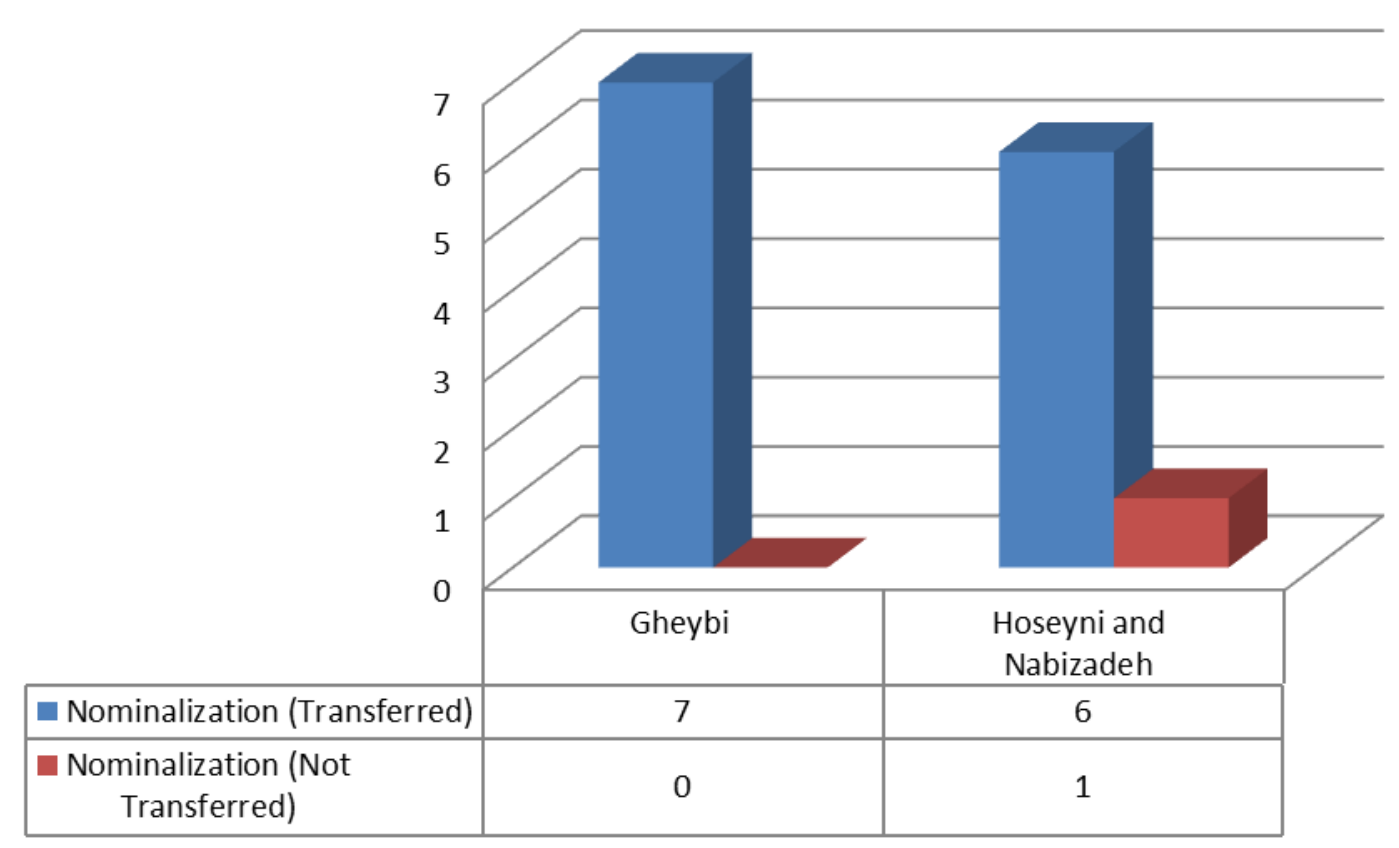

Figure 3. Nominalization Transferred by the Translators

Table 3 and Figure 3 show that Gheybi (2011) has managed to transfer nominalization 7 times out of 7 (100\% percent) in her Farsi translation. In Farsi translation B, Hoseyni and Nabizadeh have managed to transfer nominalization 6 times out of 7 (86\% percent). On the other hand, Gheybi (2011) has not missed any nominalized item in her Farsi translation. In Farsi translation B, Hoseyni and Nabizadeh have failed to transfer nominalization once out of 7 (14\% percent). This means that the first Farsi translator was more successful in rendering nominalization from English into Farsi. That is, Farsi translation A is better equivalence of the original English ST than Farsi translation B.

Table 4. Passivization Transferred by the Translators

\begin{tabular}{lllll}
\hline Translators & Gheybi (Farsi) & $\begin{array}{l}\text { Hoseyni } \\
\text { (Farsi) }\end{array}$ & and & Nabizadeh \\
\hline Criterion & Yes & No & Yes & No \\
\hline Passivization & 19 & 0 & 5 & 14 \\
\hline
\end{tabular}




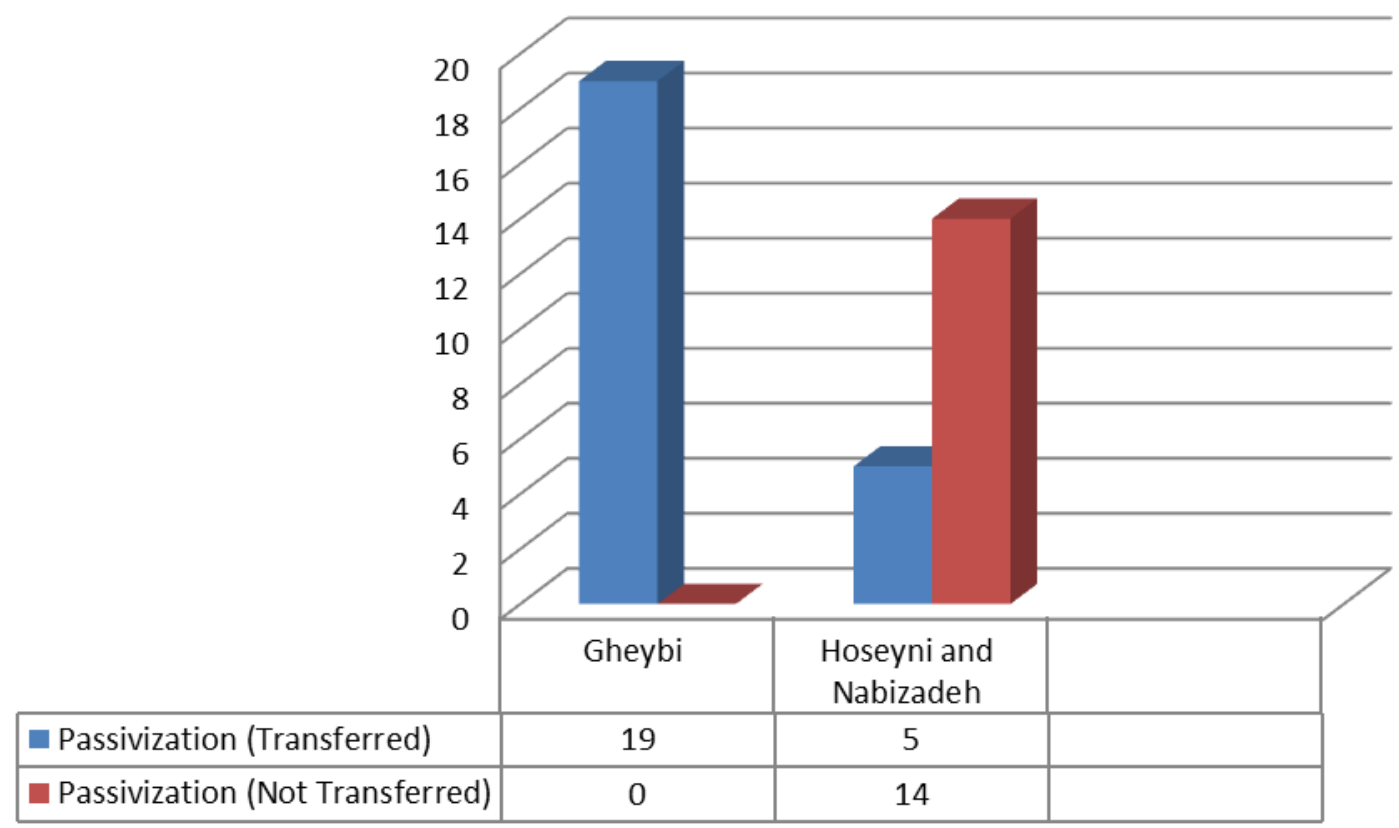

Figure 4. Passivization Transferred by the Translators

According to Table 4 and as shown in Figure 4, Gheybi (2011) has managed to transfer passivization 19 times out of 19 (100\% percent) in her Farsi translation. In Farsi translation B, Hoseyni and Nabizadeh (2003) have managed to transfer passivization 5 times out of 19 (26\% percent). On the other hand, Gheybi (2011) has not failed to transfer any passive verb in Farsi translation. Hoseyni and Nabizadeh (2003) have failed to transfer passivization 14 times out of 19 (74\% percent). This means that the first Farsi translator was more successful in passivization than other translation. That is, Farsi translation A is better equivalence of the original English ST than Farsi translation B.

Table 5. Modality Transferred by the Translators

\begin{tabular}{lllll}
\hline Translators & Gheybi (Farsi) & $\begin{array}{l}\text { Hoseyni } \\
\text { (Farsi) }\end{array}$ & and & Nabizadeh \\
\hline Criterion & Yes & No & Yes & No \\
\hline Modality & 22 & 2 & 12 & 12 \\
\hline
\end{tabular}

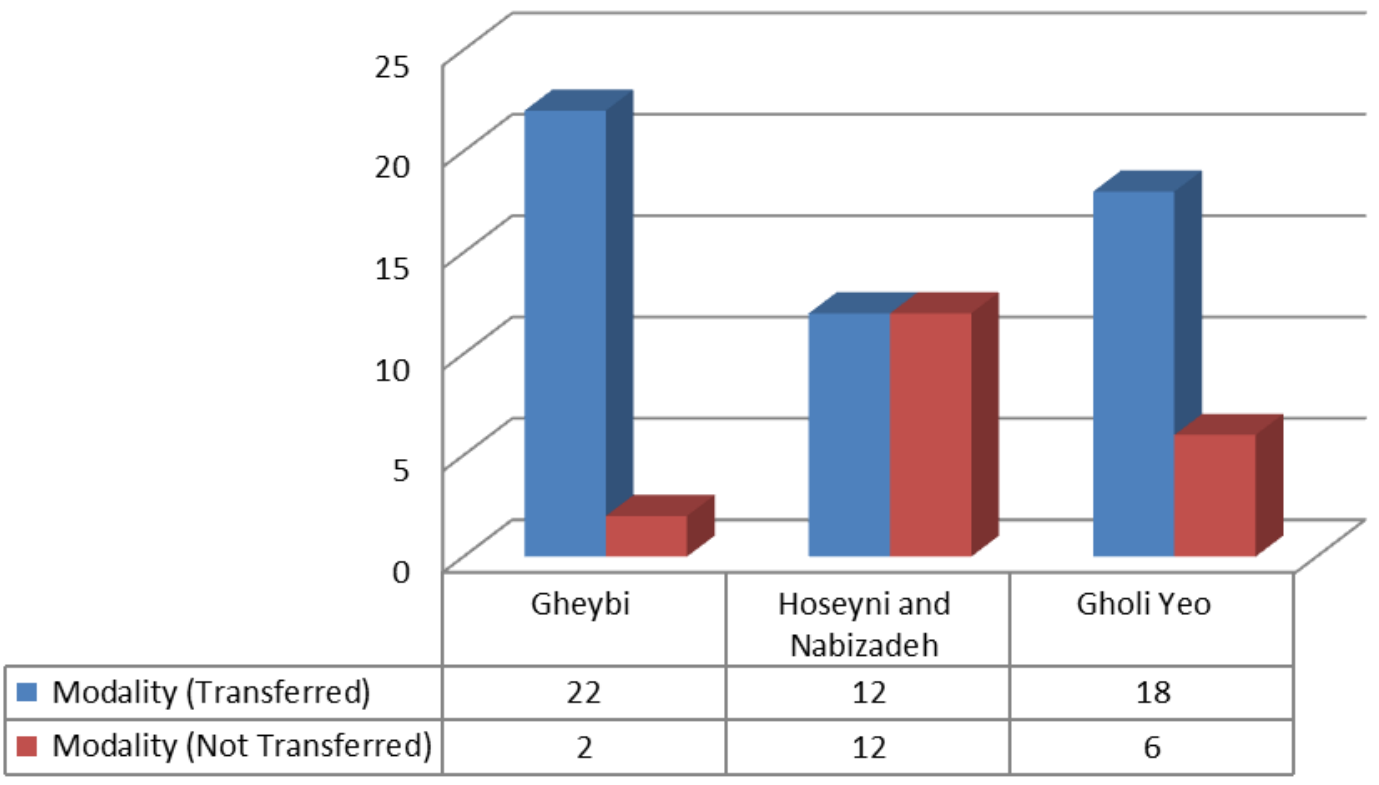

Figure 5. Modality Transferred by the Translators

Table 5 and Figure 5 show that Gheybi (2011) has managed to transfer modality 22 times out of 24 ( $92 \%$ percent) in her Farsi translation. In Farsi translation B, Hoseyni and Nabizadeh (2003) have managed to transfer modality 12 times out 
of 24 (50\% percent). On the other hand, Gheybi (2011) failed to transfer modality 2 times out of 24 (8\% percent) in her Farsi translation. In Farsi translation B, Hoseyni and Nabizadeh have failed to transfer modality 12 times out of 24 (50\% percent). This means that the first Farsi translator was more successful in rendering modality than other translation. That is, Farsi translation A is better equivalence of the original English ST than Farsi translation B.

Table 6. The Conceptual Discourse Patterns transferred by the Translators

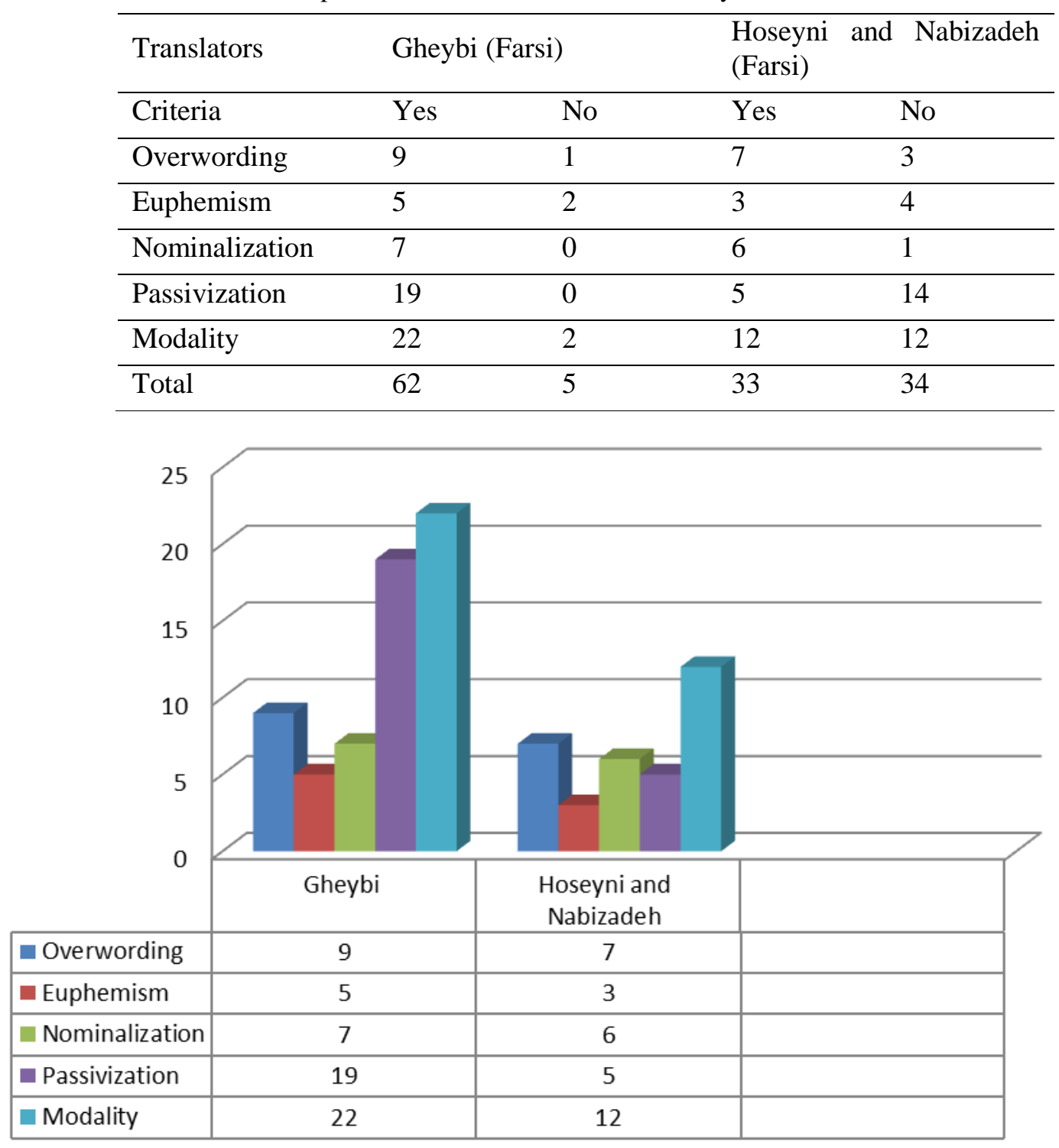

Figure 6. The Conceptual Discourse Patterns transferred by the Translators

According to Table 6, as shown in Figure 6, Gheybi (2011) has managed to transfer the conceptual discourse patterns through the criteria 62 times out of 67 (93\% percent) and failed to transfer the discoursal patterns 5 times out of 67 (7\% percent). Hoseyni and Nabizadeh (2003) have managed to transfer the conceptual discourse patterns 33 times out of 67 ( $49 \%$ percent) and failed to transfer these patterns 34 times out of 67 (51\% percent). This means that the first Farsi translator was more successful in rendering the conceptual discourse patterns than other translation. That is, Farsi translation A is better equivalence of the original English ST than Farsi translation B.

Table 7. The Ideology transferred by the Translators

\begin{tabular}{lllll}
\hline Translators & Gheybi (Farsi) & $\begin{array}{l}\text { Hoseyni } \\
(\text { Farsi) }\end{array}$ & and & Nabizadeh \\
\hline Criteria & Yes & No & Yes & No \\
\hline Overwording & 10 & 0 & 9 & 1 \\
\hline Euphemism & 5 & 2 & 5 & 2 \\
\hline Nominalization & 7 & 0 & 6 & 1 \\
\hline Passivization & 15 & 0 & 4 & 11 \\
\hline Modality & 16 & 2 & 8 & 10 \\
\hline Total & 53 & 4 & 32 & 25 \\
\hline
\end{tabular}




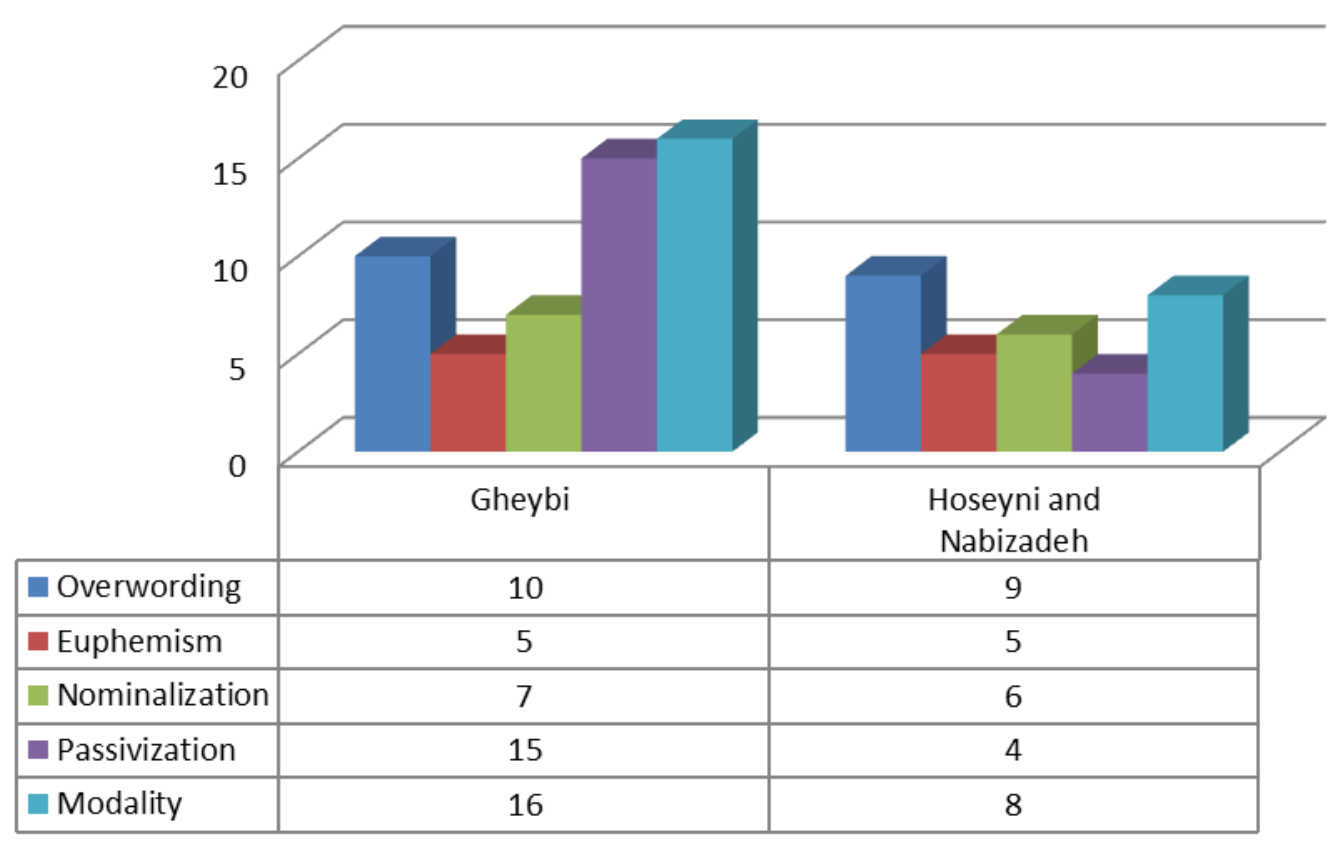

Figure 7. The Ideology transferred by the Translators

According to Table 7, as shown in Figure 7, Gheybi (2011) has managed to transfer the ideologies through the criteria 53 times out of 57 (93\% percent) and failed to transfer the ideologies 4 times out of 57 (7\% percent) in Farsi translation. In Farsi translation B, Hoseyni and Nabizadeh (2003) have managed to transfer ideologies 32 times out of 57 (56\% percent) and failed to transfer ideological concepts 25 times out of 57 (44\% percent). This means that the first Farsi translator was more successful in transferring the ideologies than other translation. That is, Farsi translation $\mathrm{A}$ is better equivalence of the original English ST, than Farsi translation B.

\section{Conclusion, Implications and Suggestions}

The findings of the present research indicated that the ideological and socio-cultural norms of translators affect their translation strategies and lexical and grammatical choices and this in turn influences their success to recognize and transmit the ST implicit ideologies into TT. It shows that different experiences from the happenings or relationships in the world by various persons from various cultures influence their discoursal patterns and ideological expressions.

According to the CDA-based content analysis, the researchers concluded that Orwell has used different strategies for presenting some socio-cultural concepts and ideological manifestations in his novel. These strategies, according to Fairclough's (2001) model, are overwording, euphemism, nominalization, passivization, and using modal verbs.

In order to answer the research questions, the researchers scrutinized two translations totally to examine the renderings of Orwell's discoursal patterns by the translators. It became apparent that in Farsi translation A, Gheybi (2010) has been more successful in rendering the conceptual discourse patterns. It demonstrated that she has considered the structural features in vocabulary and grammatical levels in addition to the socio-cultural context of the source text that helps the translator transfer the concepts and meanings to target language. Furthermore, it can be said that Farsi translation by Hoseyni and Nabizadeh (2003) was not successful and translators have failed to apply ST structural features for example passive verbs in their translation, to construct the similar conceptual features in TT.

It should be emphasized that ignoring culture-bound criteria such as euphemistic expressions as we can see in Farsi translation B have led the translators to encounter problems in conveying the conceptual discourse patterns.

Needless to say, the significant role of ideology is clear in both translation process and product. The present study tried to inquire the importance of translation process in rendering ideological concepts. Focusing on the ideologies and power relations behind any lexical and grammatical choices in the source and target texts and based on the results, the researchers explored the manipulation of Orwell's ideologies and existing power relations through the discursive structures in the three translations.

Findings of the research for two questions showed that Farsi translation by Gheybi (2010) could be considered as a more successful Farsi translation of this novel. This translation clearly indicated the relation between considering conceptual discourse patterns and recognizing embedded ideologies. In other words, the findings of this study following Orwell's or speaker's conceptual discourse patterns lead us to make explicit the ST implicit ideologies or power relations in TTs.

On the other hand, the results also indicate that the use of CDA as a framework can be as an appropriate tool for analyzing translation in terms of discursive and ideological aspects. Therefore, through a qualitatively comparative and analytical approach, CDA provides translation students, translators, and TS researchers with meticulously comprehensive viewpoints on literary texts and their translations. In fact, CDA offered a framework that uncovered the implicit ideological content as well as the ways in which ideology was expressed, reinforced, and observed in a source text and its translations. 
It is clear that language is used to convey culture and ideology from one society to another. In translating an example of language use, the translators cannot be neutral. Therefore, being aware of how this transition takes place can be significant for translators. As Van Dijk (1993, p.29) contends, the text (written or spoken) is like "an iceberg of information" and it is only the "tip" which is really expressed in words and sentences. Therefore, it can be concluded that the analysis of the implicitness is very helpful in the study of the underlying ideologies. Theoretically, the findings of this study can shed a light on the methods of discourse analysis that can systematically help the translators clarify hidden ideologies.

On the other hand, literary texts inspire readers' minds with intellectual insights and enforce them to ponder the social problems. Hence, the development of critical discourse analysis methods is crucial in linguistics and TS. A comparative CDA of ST and its translations can provide a broader analytical angle for translation students and can help them recognize texts in connection with all contextual features such as ideology, power relations, and cultural and historical backgrounds. Therefore, the findings of the present research can give the translators a deeper insight towards subtle persuasive strategies that place readers in specific ideological positions. Overall, this study shows the importance of CDA in the process of translating.

Findings of the present study may also have some other implications for the translators. Following similar procedure can help them realize the important implicit ideological items in source text and difficulties in transferring them into the target text. This researcher tried to clarify this process by investigating the conceptual patterns and ideologies in ST and TTs. On the other hand, the obtained results proved the fact that the application of CDA for analysis of the ST and TTs helps the translators become aware of the social and situational context of the ST and TTs, and outlines the power formation and ideological relations on the discoursal level. In fact, some authors construct and embed special ideologies in their works that create special social images in readers' minds. Therefore, by more manipulation of original ideologies by the translators, different images will be created in the target readers' minds. Therefore, the response and feedback that are received from the source and target readerships would be very different.

Those who take part in critical discourse analysis projects, translators in particular, may also benefit from the findings of this research as a pattern to learn what to do while analyzing ideological topics or how translators can realize the structural discourse patterns and related conceptual patterns in literary texts or other ideologically significant genres even poems as we can see in this novel. Further, the results can be useful for translators in criticizing and evaluating their own translations.

Translation as a bridge between various discourses plays a big role in the development of discourse. According to Schaffner (2004, p.118), it is through translation that information is made available to addressees beyond national borders. Investigating the discoursal patterns and ideologies in English source text and Farsi target texts gives the translators a chance to compare three different cultural discourses through CDA.

As previously mentioned, the present paper focused on the process of investigating the conceptual patterns and ideological topics on one political novel as the source material and its Farsi translations, i.e., different cultures, according to critical discourse analysis approach. The following two issues could also be suggested for further research:

1. To conduct research on ingenious strategies such as dysphemism in order to analyze the textual features.

2. To conduct research on investigating conceptual discourse patterns and ideological terms in a verbal speech against its written versions and its translations to clarify the effects of the items that translators cannot transfer in written language such as voice, tone, and body language.

\section{References}

Aidinlou, N. A., Dehghan, H. N., \& Khorsand, M. (2014). Ideology, Change \& Power in Literature and Society: A Critical Discourse Analysis of Literary Translations. International Journal of Applied Linguistics and English Literature, 3(6), 260-271.

Bahaa-eddin, M. M. (2014). CDA and PDA Made Simple: Language, Ideology and Power in Politics and Media. Cambridge: Cambridge Scholars Publishing.

Bublitz, W. \& Lenk, V. (1997). Coherence in Spoken and Written Discourse. Selected Papers from The International Workshop On Coherence. Amsterdam/ Philadelphia: John Benjamin Publishing Company.

Crespo-Fernández, E. (2014). Euphemism and Political Discourse in the British Regional Press. Brno Studies in English, 40 (1): 5-26.

Dooley, R. A. (2008). Relevance Theory and Discourse Analysis: Complementary Approaches for Translator Training. Dallas, Texas: Graduate Institute of Applied Linguistics. Retrieved From www.Gial.Edu/Gialens/Issues.Htm.

Fairclough, N. (1989). Language and Power. London, UK: Longman.

Fairclough, N. (1992), Discourse and Social Change. UK: Polity press in Association with Blackwell Publishing Ltd.

Fairclough, N. (1992a). Discourse and Social Change. Cambridge, UK: Polity Press.

Fairclough, N. (1992b). Discourse and Text: linguistics and intertextual analysis within discourse analysis. Discourse and Society, 3(2): 193-217.

Fairclough, N. (2001). Language and Power (Second Edition). London: Longman 
Fairclough, N. (2003). Analyzing Discourse. Textual Analysis for Social Research. London \& New York: Routledge.

Fairclough, N. (2013). Critical discourse analysis: The critical study of language. London: Routledge.

Fowler, R. (1991). Linguistic Criticism. Oxford: Oxford University Press.

Gheybi, M. (2011). Mazra'iyi hiyvānāt [Animal Farm]. Tehran: Rahnama Publication.

Hoseyni, S. \& Nabizadeh, M. (2003/1383). Mazra-E-Hyvanat [Animal Farm]. Tehran: Entesharate Doostan.

Lafta, K. A. (2015). The translation of idioms in George Orwell's “Animal Farm” into Arabic (Doctoral dissertation).

University of Malaya, Malaysia.

Li, Q. I. A. O. (2013). Co-existing Relationship of Power and Language: Critical Discourse Analysis of Squealer in Animal Farm from Perspective of Power Discourse. Foreign Language and Literature, 4, 007.

Orwell, G. (1945). Animal Farm. England: Martin Secker \& Warburge.

Orwell, G. (1946). Why I Write. London: Gangrel. GB.

Richards, J. C., \& Schmidt, R. W. (2002). Longman Dictionary of Language Teaching and Applied Linguistics (Third Edition). UK: Longman.

Schäffner, C. (2003), 'Third Ways and New Centers: Ideological Unity or Difference,' In M. Calzada-Pérez (Ed.) Apropos of Ideology: Translation Studies on Ideology - Ideologies in Translation Studies (pp. 23-41). Manchester: St. Jerome.

Schaffner, C. (2004). Political Discourse Analysis from the Point of View of Translation Studies. Journal of Language and Politics, 3(1): 117-150.

Van Dijk, T. A. (1993). Principles of Critical Discourse Analysis. Discourse \& Society, 4(2): 249-283.

Van Dijk, T. A. (2001). Critical Discourse Analysis. In D. Tannen, D. Schiffrin \& H. Hamilton (Eds.), Handbook of Discourse Analysis, (pp. 352-371). Oxford: Blackwell.

Wales, K. (2014). A dictionary of stylistics. London: Routledge. 